\title{
Література:
}

1. Данилейко В. І. «Щирість, яка струменіє в усьому: в ідеї, кожному штриху, кожному мазку...». До 150-річчя від дня народження одеського художника К. Костанді // Образотворче мистецтво, 2003. № 1.21 с.

2. Киріак Костянтинович Костанді ( художник і людина) [Текст]: спогади про батька сина Михайла Киріаковича Костанді / М. К. Костанді. О.: Астропрінт, 2002. 72 с.

3. Барковська О. М., Єреміна Л. А., Щурова Т.В. Киріак Костанді і художники - греки в Одесі: Кінець XIX - початок XX століть: наукове видання / за ред. В.Ю. Сунцова. О.: Друк, 2002. 204 с.

4. Носенко А. І. Киріак Костанді. Драматургія протиставлень // Образотворче мистецтво, 2009. № $1.10-12$ с.

5. Шистер А. Н. Киріак Костанді. Л.: Художник РСФСР, 1975. 138 с.

DOI https://doi.org/10.30525/978-9934-26-004-9-52

\section{THE IMAGE OF THE CITY IN THE ART OF CHERNIVTSI OF THE 20TH - EARLY 21ST CENTURY}

\author{
Mishchenko I. I. \\ PhD in Art History, Associate Professor, \\ Associate Professor at the Art Examination Department \\ National Academy of Management of Culture and Arts \\ Kyiv, Ukraine
}

The development of the fine arts of Bukovina, particularly active in the 20 th - early 21 st century, is currently insufficiently covered in the research of the scientists. In a few publications, art critics considered mostly the works of individual authors, gave a description of the exhibitions of various exhibitions or projects, and occasionally wrote about the stylistic features of individual works. There is almost no intelligence on the specifics of the existence in the art of the region of different genres and certain topics instead. Exceptions are the editions of 2017: the album «Chernivtsi. Czernowitz» [3] and «Artistic treatises on the city that was once called Czernowitz» [1]. Therefore, it is important to study the principles of depiction of urban landscapes in the paintings and graphics of Chernivtsi artists, the peculiarities of solving their compositions and creations of the city image. 
Chernivtsi, which was actively developed in the late 19th and early 20th centuries, gathering compactly located architectural structures of several styles in the city center, including historicism, secession and constructivism, was often designed by famous architects from different European countries and has always attracted artists with its beauty. In addition, the city has a special cozy atmosphere of small streets and sophistication of buildings, which are noticeably influenced by architecture of many nations inhabiting the Bukovina region. R. Lang noted: "What Chernivtsi distinguishes is its inconspicuous, modest, in some cases almost expedient beauty. The image of the city is more convincing due to its completeness than due to its punctual brilliance. Even the most outstanding building in terms of its location and spectacular influence - a residence declared a heritage of world culture - fits into the overall picture rather restrainedly, rounding it off, instead of subjugating it to itself» [3, p. 4]. All this, as well as the work in Chernivtsi of numerous authors with unique individuality and excellent artistic orientation from the second half of the 19th century, contributed to the fact that today there is a large number of different works depicting urban landscapes and inhabitants.

The first of these works, which appeared in the early 19th century, rather captured the panorama of the city, the features of its topography, and were projects of future buildings, images of work already done or important events in the life of Chernivtsi (watercolors and graphic sheets by Eduard von Greipel, Anton Lange, J. Shubirs, Josef Hlavka, Karl Jobst, Franz Xavier Knapp etc.) [3, p. 8-10]. A careful display of the most famous architectural monuments, in particular, the ensemble of the residence of Bukovynian metropolitans and the town hall, and churches of Chernivtsi, can be found in watercolors made in the early 20th century by Eugene Maksymovych, Riccardo Rigetti, Hugo von Recori, and many other masters.

Later appeared works depicting the city's sometimes hectic existence, fairs in its squares (expressionist sheets by Oscar Laske, Georg von Löwendal), majestic buildings and inconspicuous streets, types of residents of the central streets and suburbs. Thus, in the watercolors of Karl Ewald Olszewski and Julius Helzel, Leon Koppelman of the first third of the 20th century, appeared modest and poor neighborhoods of Chernivtsi; and Augusta Kokhanovska's works were distinguished by the lack of pomp even in the image of the city's grand buildings, the sophistication of soft tonal transitions («Chernivtsi. Bukovynian Regional Administration», circa 1905).

Perhaps the largest number of Chernivtsi landscapes belongs to L. Kopelman, whose works include traditional compositions with low houses on quiet streets, and purely industrial landscapes characteristic to the art of socialist realism. His graphic sheets, watercolors and oil paintings, as well as 
the works of Rudolf Lekalov, Eugene Udin, are characterized by a combination of poetic (in E. Udin sometimes ironic) view on the city and documentary accuracy in reflecting its motifs.

Chernivtsi appears more emotional, even expressive, in the paintings of Shimon Okstein and Moritz Krinitz in the 1960s and 1970s [2, p. 63]. On the other hand, Oleksandr Litvinov's paintings of the 1990s are concise, they almost always lack human figures, and the color scheme is emphatically restrained. Gennady Gorbaty seeks to recreate the picturesqueness of Chernivtsi city center, paying special attention to the texture of the picture surface. He often saturates the landscape with eloquent elements, which reminiscent the city's past.

The romantic and sensual image of Chernivtsi was created by Natalia Yarmolchuk, whose works of the late 1980s and 1990s do not include grandiose panoramas, but chamber and poetic mises-en-scène $[4, \mathrm{p}$. 6]. The artist's city landscapes, made by watercolors and pen, are characterized by etudes, conciseness of a minimum details and means of expression; they have a noticeable anxiety, which captures the emotional state of the author.

Perhaps the greatest diversity of the image of the city is present in the works of Orest Kryvoruchko, among the exquisite paintings and graphics of which since the 1980s are the image of the most famous buildings of Chernivtsi (a series of bookplates with cathedrals of different denominations, murals), characteristic to the city roof motifs, unexpected combination in one composition of architectural details of Art Nouveau and figures of women from the suburbs, surprisingly accurate, illusory depictions of the objects of the Austro-Hungarian period on the background of an antique postcard, and so on.

Pierced by the denial of the standard idea of the city are Oleg Lyubkivsky's graphic sheets and watercolors of the 1980s - 2010s, a significant part of which is a paradoxical and refined comparison of details of the former and modern appearance of Chernivtsi, a visualized reflection of the artist on the fate of historical heritage and present [1].

In the urban art of Chernivtsi one can find different views on the image of the city: some artists rationally or enthusiastically reflect the historical monuments, the fussiness of the noisy flow of its inhabitants, others seek to recreate inconspicuous motifs that reflect the comfort and poetry of the small streets and author's own emotions. Some of the artists create a peculiar, as if turned to the past, view of the city, emphasizing the importance of certain details that tell about city's former existence. The diversity of variations not only reveals the versatility of approaches to the formation of the Chernivtsi image, but also testifies to the presence of distinctive artistic preferences in solving even thematically similar works. 


\title{
Література:
}

1. Любківський О. Художні трактати про місто, що колись називалося Czernowitz. Чернівці : Друк ФОП Глібка О. В., 2017. 460 с.

2. Митці Буковини : Енцикл. довід. / Авт.-упоряд. Т. Дугаєва, І. Міщенко. Т. 1. Чернівці : Золоті литаври, 1998. $128 \mathrm{c.}$

3. Осачук С., Дугаєва Т. Чернівці. Czernowitz : Художній альбом / Kunstalbum. Чернівці : Видавництво «Книги - XXI», 2017. 362 с.

4. Севернюк Т. Летючий промінь вічності... художник Наталя Ярмольчук. Чернівці : Золоті литаври, 2007. 304 с.

5. Ярмольчук Н. Ностальгія : Набір листівок. Чернівці, 1996.

DOI https://doi.org/10.30525/978-9934-26-004-9-53

\section{ТВОРИ ДЕКОРАТИВНО-ПРИКЛАДНОГО МИСТЕЦТВА У РОБОТАХ АНАТОЛІЯ КАЛИТКА}

\author{
Молинь Н. I. \\ викладач кафедри образотворчого мистечтва \\ та академічних дисииплін \\ Косівського інституту прикладного та декоративного мистеитва \\ Львівської національної академії мистечтв \\ м. Косів, Івано-Франківська область, Украӥна
}

Народна творчість - це підгрунтя, на основі якого розвивається мистецтво, адже кожен твір народного мистецтва - це уособлення мудрості поколінь. Народна творчість лягла в основу багатьох творів образотворчого мистецтва, надихнула багатьох художників.

Вагомою постаттю в історії образотворчого мистецтва Гуцульщини виступає Заслужений художник України, доцент кафедри образотворчого мистецтва та академічних дисциплін Косівського інституту прикладного та декоративного мистецтва Львівської національної академії мистецтв - Анатолій Миколайович Калитко [1, с. 4]. Творча та педагогічна діяльність А. Калитка в нашому навчальному закладі досягла вже півстоліття. Цьому сприяло не тільки творче обдарування художника, а й висока працездатність, намагання глибоко й правдиво відтворювати навколишню дійсність.

Плідний доробок художника відображений у трьох жанрах: портрет, пейзаж та натюрморт. А. Калитко віддає перевагу реалістичному 